\title{
Penicillin V Potassium
}

National Cancer Institute

\section{Source}

National Cancer Institute. Penicillin V Potassium. NCI Thesaurus. Code C730.

The potassium salt of penicillin $\mathrm{V}$, a member of the penicillin antibiotic family with broadspectrum bactericidal activity. Penicillin $\mathrm{V}$ binds to and inactivates penicillin-binding proteins (PBPs), enzymes located on the inner membrane of the bacterial cell wall, resulting in the weakening of the bacterial cell wall and cell lysis. PBPs participate in the terminal stages of assembling the bacterial cell wall, and in reshaping the cell wall during cell division. Inactivation of PBPs interferes with the cross-linkage of peptidoglycan chains necessary for bacterial cell wall strength and rigidity. 